\title{
Effects of a Shortened Depreciation Schedule on the Investment Costs for Combined Heat and Power Systems
}

Nicole Kranz and Ernst Worrell

\author{
Energy Analysis Department \\ Environmental Energy Technologies Division \\ Ernest Orlando Lawrence Berkeley National Laboratory \\ University of California \\ Berkeley, California 94720
}

November 2001

This work was supported by the Climate Protection Division, Office of Air and Radiation, U.S. Environmental Protection Agency through the U.S. Department of Energy under Contract No. DE-AC03-76SF00098. 


\title{
Effects of a Shortened Depreciation Schedule on the Investment Costs for Combined Heat and Power Systems
}

\author{
Nicole Kranz and Ernst Worrell \\ Energy Analysis Department, Environmental Energy Technologies Division \\ Lawrence Berkeley National Laboratory \\ Berkeley, CA 94720
}

\begin{abstract}
We investigate and compare several generic depreciation methods to assess the effectiveness of possible policy measures with respect to the depreciation schedules for investments in combined heat and power plants in the United States. We assess the different depreciation methods for CHP projects of various sizes (ranging from $1 \mathrm{MW}$ to $100 \mathrm{MW}$ ). We evaluate the impact of different depreciation schedules on the tax shield, and the resulting tax savings to potential investors. We show that a shorter depreciation cycle could have a substantial impact on the cost of producing power, making cogeneration more attractive. The savings amount to approximately $6-7 \%$ of capital and fixed operation and maintenance costs, when changing from the current system to a 7 year depreciation scheme with switchover from declining balance to straight line depreciation. Suggestions for further research to improve the analysis are given.
\end{abstract}




\section{Table of Contents}

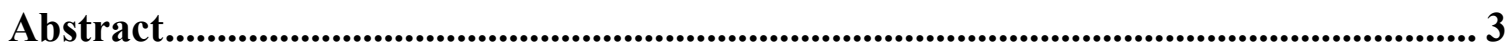

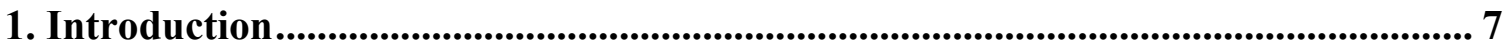

2. Combined Heat and Power .......................................................................................... 9

3. Taxation and Depreciation of CHP Investments ............................................. 10

4. Methodology ……....................................................................................................................... 13

5. Results and Discussion....................................................................................... 19

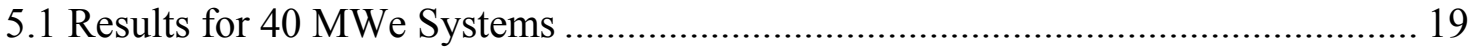

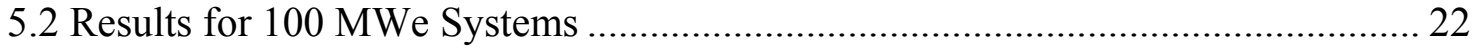

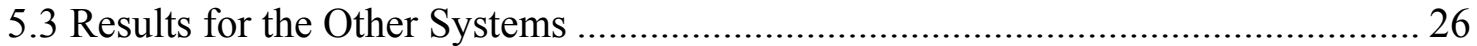

5.4 The Cost of different Depreciation Systems to the U.S. Treasury .......................... 27

5.5 Uncertainties and Recommendations for Future Research.................................... 28

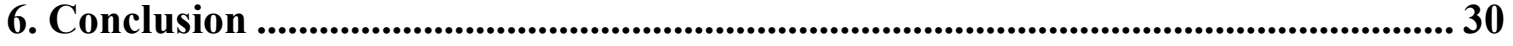

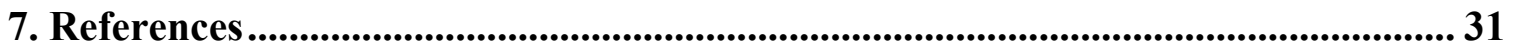




\section{Introduction}

The US power industry is currently facing a number of challenges ranging from an increased demand for electricity, aging equipment, as well as stricter environmental standards. New investments in power generation to replace aging equipment or to provide new power are needed. It has been widely accepted by experts that an increased use of cogeneration or combined heat and power production (CHP) would help to meet the challenges. In order to increase the use of CHP for power generation in the US the US Department of Energy and the US Environmental Protection Agency, issued the so-called CHP challenge in 1998. The CHP Challenge demands an increased cooperation between industry and governmental institutions with the goal of doubling CHP capacity in the US and to reach an overall capacity of $100 \mathrm{GW}$ by the year 2010.

Although CHP technologies have improved significantly during the past years, still many predominantly regulatory and market barriers exist that discourage increased investments in CHP. These barriers include a general lack of awareness of the benefits offered by CHP, environmental permitting, interconnection with the grid, as well as economic barriers (including depreciation and ownership). In response to these barriers U.S. Congress is currently working on new legislation allowing for a better integration of CHP into the existing power supply structure, as well as creating considerable incentives for increased investments in CHP. During the summer of 2001 several draft proposals were submitted featuring tax credits, changes of the depreciation schedules for CHP plants or a combination of those measures. A recent bill passed by the US House of Representatives on August $4^{\text {th }}, 2001$ is the comprehensive energy bill, called the SAFE act. The SAFE-act includes new CHP tax credit language according to which new CHP systems with a capacity of more than $50 \mathrm{~kW}$, and which produce at least 20 percent of their useful energy in form of thermal energy and at least 20 percent in the form of electrical or mechanical power, are entitled to a ten percent investment tax credit. In the proposed language the depreciation period for those assets will be extended from 15 to 22 years, when the tax credit would be accepted.

The US Combined Heat and Power Association (USCHPA) considers this tax credit language a good starting point for the legislative goals of various CHP stakeholders. The USCHPA also pointed out that further adjustments need to be made concerning the $50 \mathrm{~kW}$ minimum size restriction and most importantly with respect to the depreciation of CHP investments. Various CHP experts and advocates have discussed and recommended a shortened depreciation period as one of the main incentives for new investments in CHP technologies.

In order to assess the effectiveness of possible policy measures with respect to the depreciation schedules as they apply to CHP investments, this paper investigates and compares several generic depreciation scenarios. The financial impact of the depreciation scenarios is investigated. We assess the different depreciation methods (or scenarios) for CHP projects of various sizes (ranging from $1 \mathrm{MW}$ to $100 \mathrm{MW}$ ). We evaluate the impact of different depreciation schedules on the tax shield, and the resulting tax savings to potential investors. In order to allow for a general 
approach, various assumptions concerning the model calculations had to be made. After a discussion of the advantages of CHP and current tax rules for CHP in the United States, we describe the methodology used, as well as the assumptions used in the study. This is followed by the presentation and discussion of the results, followed by conclusions and suggestions for further research. 


\section{Combined Heat and Power}

Combined heat and power technologies have various advantages over conventional power generating systems. One of the primary benefits is the more efficient delivery of energy in the form of thermal and electric energy. This is largely due to the recovery of heat that is usually not utilized in conventional energy generating systems, but which makes up for 40 to 70 percent of the heat input into those systems. Cogeneration recovers this thermal energy for useful applications like process heat (in industry) or heating (buildings), thus increasing the overall efficiency of a system to 80 percent or higher. The heat can also be used for cooling using absorption cooling systems. Combined heat and power technologies are mostly realized as relatively small power units of typically less than $50 \mathrm{MW}$ near or on the respective energy user's property, which is also referred to as distributed generation. However, larger systems may be found in industry and district heating systems. Micro-turbines $(<50 \mathrm{~kW})$ can also be used in cogeneration applications. Transmission and distribution benefits can be obtained due to more reliable and flexible distribution and less expensive T\&D systems as the energy users are generally located near the cogeneration plant.

The efficiency improvements with respect to the generation and the distribution of energy are likely to result in environmental benefits due to reduced emissions per unit of energy delivered. In comparison with other power generating technologies distributed CHP results in lower $\mathrm{NO}_{\mathrm{x}}$ as well as $\mathrm{CO}_{2}$ emissions. The shift to gas (the most commonly used fuel in modern cogeneration projects) would also result in reductions in SOx if replacing coal fired power stations or boilers. Another aspect of the distributed power generation is related to the decentralization of emissions from central power generating units. This could be regarded as a considerable benefit, however a close monitoring of the distribution of emissions of decentralized cogeneration is necessary, taking into consideration that these plants are likely to be located closer to the end user (Major and Davidson, 1998). 


\section{Taxation and Depreciation of CHP Investments}

Depreciation is the decrease in value of physical properties with time and use. As an accounting concept, depreciation induces an annual deduction of before-tax income reflecting the effects of time and use on a company's assets. Consequently, depreciation indirectly results in a reduction of the income taxes payable. The annual depreciation deductions are intended to 'match' the yearly fraction of value used by an asset in the production of income over the asset's actual economic life. However, the actual amount of depreciation can never be established until the asset is retired from service.

A company can begin to depreciate property it owns when the property is placed in service for use in the business or for the production of income. This is the case when property is ready and available for a specific use, even if it is not actually used yet. Depreciation stops either when the cost of placing it in service has been recovered or it is retired from service.

Over time, the methods for calculating the depreciation permitted by the Internal Revenue Service under the Internal Revenue Code have evolved from the simple straight-line method of depreciation to more complicated, but also more favorable accelerated depreciation schemes over time. The brief description of the historical development in the next paragraph is followed by a more detailed discussion of the most important depreciation methods.

Prior to the enactment of the Accelerated Cost Recovery System (ACRS) in 1981, cogeneration systems, together with most of the other capital equipment, were generally depreciated according to the Asset Depreciation Range-system (ADR). Under ADR, the applicable depreciation period for most types of cogeneration property ranges from a low of 17.5 years to a high of 26.5 years and averages 22 years. In contrast, ACRS, implemented under the Economic Recovery Tax Act (ERTA) of 1981 and applicable to equipment put into service in that year or after, has a special provision for cogeneration equipment. The ACRS provided for cogeneration equipment, which is not public utility property and has an economically useful life span of 12 to 25 years, to be qualified as five-year property, thus significantly reducing the federal depreciation period for new cogeneration investments - by an average of about 17 years.

With the enactment of the Tax Reform Act in 1986 (TRA 86), one of the most extensive income tax reforms in the history of the United States, an altered version of the ACRS, called Modified Accelerated Cost Recovery System (MACRS) was introduced for the depreciation of tangible property placed in service after 1986. Consequently ACRS and other depreciation methods still apply to equipment placed in service before 1986 or 1981 respectively.

Although ACRS and MACRS might share some terminology these two depreciation systems are intrinsically different. In contrast to the ACRS, the MACRS recognizes salvage value but assigns it a value of zero. Also, pursuing MACRS' specific conventions (see below) the cost of 3-year, 5year or 10-year property placed in service under MACRS generally must be recovered over one 
more tax year (four, six or eleven years) as compared to the cost of similarly named classes of property placed in service under ACRS. Another basic distinction is that in contrast to ACRS, under which the annual deduction is generally a designated percentage of the unadjusted basis, MACRS may require appropriate basis adjustments to compute second and subsequent-year deductions. Optional MACRS tables furnished by the IRS provide percentages that are applied to the unadjusted basis of a property in a manner similar to statutory percentages provided to compute ACRS deductions (CCH, 1997, par.80).

Under MACRS, tangible depreciable property is categorized into asset classes. The property in each asset class is assigned a class life, a GDS (General Depreciation System) recovery period and an ADS (Alternative Depreciation System) recovery period. These are the two systems used for calculating depreciation under MACRS. While the GDS, the main depreciation system, uses accelerated depreciation over various periods, ADS provides a longer recovery period and uses only straight-line depreciation. Property that is placed in any tax-exempt use and property used predominantly outside the United Sates are examples of assets that must be depreciated under ADS. Any property that qualifies for GDS can also be depreciated under ADS if elected.

Under GDS most tangible personal property is assigned to one of the six personal property classes (3-,5-,7-,10-,15- and 20-year property). The depreciation is calculated as described in the following. The $200 \%$ declining balance method with switchover to straight-line is used for the GDS personal property classes of 3, 5, 7, and 10 years, while the $150 \%$ declining balance method is used for the 15- and 20-year property. Other property classes are the real property classes for residential and non-residential property. Straight-line depreciation is used for the non-residential and residential real property classes. Under ADS straight-line depreciation is used for both personal and real property classes.

In computing MACRS deductions for the tax year in which property is placed in service and the year of disposition, averaging conventions are used to establish when the recovery period begins and ends. Averaging conventions apply to depreciation computations made under regular MACRS method, the straight-line MACRS method, and the alternative MACRS method. The recovery period begins on the date specified under the applicable convention. The same convention that is applied to the depreciable property in the tax year in which it is placed in service must also be used in the tax year of disposition ( $\mathrm{CCH}, 1997$, par.86). The three applicable forms of conventions are the half-year convention, the mid-month convention and the mid-quarter convention, with the half-year convention being the one applicable to combined heat and power equipment. Under the half-year convention, the recovery period begins or ends at the midpoint of the tax year. Thus, one-half of the depreciation for the first year of the recovery period is allowed in the tax year in which the property is placed in service. Also, a half-year of depreciation is allowed in the tax year in which the recovery period ends. 


\section{Current depreciation treatment of CHP}

Under the MACRS depreciation schedule, CHP systems are treated differently depending on ownership and usage. A 15 year-schedule applies to systems at industrial sites producing electricity/steam, which is not ordinarily available for sale to others. The depreciation method applied here is the $150 \%$ declining balance method (CCH, 1997, par.190). A 20 year-schedule is used for systems utilized for the production/ distribution of steam for sale. Again, the applicable depreciation method here is the $150 \%$ declining balance method ( $\mathrm{CCH}, 1997$, par.190). Much longer depreciation periods apply to CHP systems used in commercial residential building. Whereas a 27.5-year schedule applies to rental property a depreciation period of 39 years is demanded for buildings, which are occupied or utilized by the owner. In both cases a straight-line depreciation method is used to determine the annual tax shield ( $\mathrm{CCH}, 1997$, par.190).

Many experts on cogeneration agree that neither of these depreciation schedules realistically reflects the true life of the cogeneration systems, which is estimated to range between 5 and 10 years. This is mostly due to the fact that in distributed cogeneration the equipment is usually used constantly totaling about 8000 operating hours per year as opposed to lower numbers of operating hours for conventional large scale power generating equipment with an average life-time of 25 , sometimes even 35 years (Casten \& Hall, 1998). 


\section{Methodology}

In order to explore the effect of shortening the depreciation cycle to seven years for CHP equipment, six different scenarios were considered in our analysis to calculate the annual depreciation:

- Straight-line depreciation

$\circ$ for a 15-year depreciation schedule,

- for a 7-year depreciation schedule,

- Depreciation with the declining balance method using a:

○ $150 \%$ declining balance method for 15 -year depreciation schedule,

○ $200 \%$ declining balance method for 7 -year depreciation schedule,

- Depreciation with the declining balance method with a switchover to straight-line depreciation

- for a 15-year depreciation schedule and,

$\circ$ for a 7-year depreciation schedule.

Below, we will shortly outline each of the applied depreciation methods.

Straight-line depreciation

Straight-line depreciation is the simplest depreciation method. It assumes that a constant amount is depreciated each year over the depreciable life of the asset. The annual depreciation under the straight-line method is calculated by subtracting the salvage value of the end-of-life equipment (SV) from the cost basis, i.e. the depreciable capital investment (B) and dividing the result by the depreciable life of the asset in years $(\mathrm{N})$ :

$\mathrm{d}_{\mathrm{k}}=\left(\mathrm{B}-\mathrm{SV} \mathrm{V}_{\mathrm{N}}\right) / \mathrm{N}$

With $\mathrm{d}_{\mathrm{k}}$ being the annual depreciation deduction in year $\mathrm{k}$, the cumulative depreciation over the years can be calculated by multiplying the respective annual depreciation by the number of years elapsed (k):

$\mathrm{d}_{\mathrm{k}} *=\mathrm{k} \mathrm{d}_{\mathrm{k}}$ for $1<\mathrm{k}<\mathrm{N}$

The book value, $\mathrm{BV}_{\mathrm{k}}$, at the end of year $\mathrm{k}$, can be calculated by subtracting the cumulative depreciation from the initial cost basis:

$\mathrm{BV}_{\mathrm{k}}=\mathrm{B}-\mathrm{d}_{\mathrm{k}} *$

The simplicity of the calculation itself is complicated by the necessity to make an accurate estimation of the salvage value, i.e. the final book value at the end of year $\mathrm{N}$, which may not always be equal to the asset's actual terminal market value. Consequently the true depreciation can only be calculated after the equipment was taken out of use (Sullivan et al. 2000). 
Depreciation with the declining balance method

The declining balance method, also known as the constant percentage method or the Matheson formula, calculates the annual depreciation as a fixed percentage of the asset's book value at the beginning of the year. The ratio of the depreciation in any one year to the book value at the beginning of the year is constant throughout the life of the asset and is designated by the percentage factor $\mathrm{R}(0<\mathrm{R}<1)$. The methods applied most frequently are the $200 \%(\mathrm{R}=2 / \mathrm{N})$ and $150 \%(\mathrm{R}=1.5 / \mathrm{N})$ declining balances, which doubles or multiplies by 1.5 the annual depreciation according to straight-line conditions $(1 / \mathrm{N})$.

The following equations allow for the calculation of the annual depreciation, the cumulative depreciation through $\mathrm{k}$, the respective book value in year $\mathrm{k}$ and the book value at the end of the asset's depreciable life. Due to the constant depreciation rate, it is not necessary to know the asset's salvage value (Thuesen et al. 2001):

$\mathrm{d}_{\mathrm{k}}=\mathrm{B}(1-\mathrm{R})^{\mathrm{k}-1}(\mathrm{R})$

$\mathrm{d}_{\mathrm{k}} *=\mathrm{B}\left[1-(1-\mathrm{R})^{\mathrm{k}}\right]$

$\mathrm{BV}_{\mathrm{k}}=\mathrm{B}(1-\mathrm{R})^{\mathrm{k}}$

$B V_{N}=B(1-R)^{N}$

\section{Declining Balance with Switchover to Straight-Line}

Due to the fixed percentage rate used by the declining balance method, a book value of zero can never be reached. It is also possible that after a few years it is more profitable to depreciate under straight-line condition than to further employ the declining balance method. Therefore it is permissible to switch from this method to the straight-line method so that an asset's $\mathrm{SV}_{\mathrm{N}}$ will be zero (or some other desired amount). This method is also used in calculating the MACRS recovery rates.

The switchover occurs in the year in which a larger depreciation amount is obtained from the straight-line method. Switching allows for the full cost basis to be depreciated over the respective recovery period (Sullivan et al. 2000).

\section{Estimating the Impact on Project Costs of the Different Depreciation Methods}

First, the six methods mentioned above were applied in order to calculate the annual depreciation, the cumulative depreciation over the life of the asset and the respective book value for each year of the asset's life. Then, the annual depreciation value was multiplied by a $35 \%$ tax rate in order

to derive the annual tax savings from deductible business expenditures, in finance literature also referred to as tax shields. The net present value of these tax shields was calculated assuming a $7 \%$ discount rate. The tax savings were subtracted from the total project cost, which included all 
capital costs as well as the operational and maintenance expenses throughout the equipment's lifetime, which was assumed to be 15 years.

Finally, the cost to produce one $\mathrm{kWh}$ was derived to allow direct comparison of the project costs of different depreciation methods and projects. For this calculation it has to be taken into consideration that it only gives an approximate value of the actual costs incurred, as the income (from electricity and heat sales) and the actual taxes that have to be paid are not included. Therefore, the cost per kWh should not necessarily be considered as an absolute value but rather as a (relative) means to allow comparison of the effects of the depreciation methods. The income may vary widely based on regional variations in electricity markets and fuel costs. Also, in our estimates we have assigned all costs to electricity production, i.e. the cost per $\mathrm{kWh}$ only relates to the production of electrical power and does not account for the sales of heat. We assume a lifetime of 15 years and an availability of 8000 hours/year.

The tax shield serves as a good means of comparing the different depreciation schedules. As no information about the revenue of power generation is provided, it is actually not possible to determine the actual tax payment - as this is dependent on the pretax profit-, but only the benefits resulting from depreciation. However, it is obvious that a larger tax shield makes the investment in the specific power equipment more attractive and therefore the tax shield can serve as an indicator for the benefits arising from applying a certain depreciation method.

\section{Assumptions}

In calculating the scenarios, several assumptions concerning data, depreciable investments, asset class and recovery period, applied depreciation method, the tax and discount rate had to be taken.

Capital and operating and maintenance costs for six typical gas turbine CHP systems varying from site ratings of $1 \mathrm{MW}$ to $100 \mathrm{MW}(1 \mathrm{MW}, 5 \mathrm{MW}, 10 \mathrm{MW}, 25 \mathrm{MW}, 40 \mathrm{MW}$ ) were taken from estimations provided by ONSITE Energy Corporation. The ONSITE evaluation of cost and performance characteristics were derived from published performance specifications contained in various trade publications and ONSITE's own experience in installing and specifying similar equipment (Hedman, 2001). 
Table 1: Capital cost estimates for industrial CHP plants based on combustion turbines. Source: Onsite Energy Corp. (Hedman, 2001).

\begin{tabular}{|c|c|c|c|c|c|c|}
\hline Nominal Turbine Capacity MW & 1 & 5 & 10 & 25 & 40 & $100 *$ \\
\hline Heat Recovery Steam Generators & $\$ 250,000$ & $\$ 350,000$ & $\$ 590,000$ & $\$ 1,020,000$ & $\$ 2,040,000$ & $\$ 7,000,000$ \\
\hline Water Treatment System & $\$ 30,000$ & $\$ 100,000$ & $\$ 150,000$ & $\$ 200,000$ & $\$ 225,000$ & $\$ 750,000$ \\
\hline Electrical Equipment & $\$ 150,000$ & $\$ 375,000$ & $\$ 625,000$ & $\$ 990,000$ & $\$ 1,500,000$ & $\$ 5,600,000$ \\
\hline Materials & $\$ 143,952$ & $\$ 356,723$ & $\$ 688,512$ & $\$ 1,190,746$ & $\$ 2,053,792$ & $\$ 3,626,250$ \\
\hline Labor & $\$ 347,509$ & $\$ 908,023$ & $\$ 1,752,576$ & $\$ 3,030,989$ & $\$ 4,723,722$ & $\$ 9,670,000$ \\
\hline Total Process Capital \$ & $\$ 1,616,461$ & $\$ 4,507,686$ & $\$ 8,700,288$ & $\$ 15,046,694$ & $\$ 27,315,434$ & $\$ 61,646,250$ \\
\hline General Facilities Capital \$ & $\$ 48,483$ & $\$ 135,231$ & $\$ 261,009$ & $\$ 451,401$ & $\$ 819,463$ & $\$ 1,849,388$ \\
\hline Engineering and Fees $\$$ & $\$ 48,483$ & $\$ 135,231$ & $\$ 261,009$ & $\$ 451,401$ & $\$ 819,436$ & $\$ 1,849,388$ \\
\hline Process Contingency $\$$ & $\$ 48,483$ & $\$ 135,231$ & $\$ 261,009$ & $\$ 451,401$ & $\$ 819,436$ & $\$ 1,849,388$ \\
\hline Project Contingency $\$$ & $\$ 171,305$ & $\$ 477,815$ & $\$ 922,231$ & $\$ 1,594,436$ & $\$ 2,895,436$ & $\$ 6,534,503$ \\
\hline
\end{tabular}

According to the Internal Revenue Code it is only admissible to depreciate property if it is used for business or held for the production of income, if it has a determinable useful life exceeding one year and if it wears out, decays and becomes obsolete or loses value from natural causes (CCH, 1997, par.3). Labor equipment and material costs as well as engineering fees and project contingencies cannot be depreciated (CCH, 1997, par.3). Similarly operating and maintenance cost are not subject to depreciation. Hence, the depreciable investments are limited to the actual capital outlay, i.e. combustion turbine, steam turbine (if applicable), heat recovery steam generators, water treatment system, electrical equipment, other equipment and materials used directly in capital outlay.

Also, with assets consisting of several parts it is possible that these are depreciated according to different schedules. For simplification reasons it is assumed that all parts of the systems examined are depreciated over the same period.

\section{Asset class, class life and recovery period}

In response to the data provided the asset class examined in this study is MACRS class 00.4 "Industrial steam and electrical generation and/or distribution systems". This asset class was assigned a class life of 20 years, a GDS recovery period of 15 years and an ADS recovery period of 20 years. Therefore, the base case computes the tax shield for a straight-line and declining balance depreciation over 15 years, whereas the alternative case considers a shorter depreciation schedule of 7 years, which has been endorsed by various stakeholders.

Rather than using the pre-calculated annual percentage depreciation rates as supplied by the IRS, the deductions were computed by calculating the depreciation rate $\mathrm{R}$, which stays constant for each tax year and is applied to the unrecovered basis of the property. Also, in this study the application of the half-year convention was neglected.

\section{$\underline{\text { Salvage Value }}$}

In calculating the annual depreciation using the straight-line method it is necessary to know the salvage value, i.e. the final book value of the asset. For simplification reasons a salvage value of 
\$0 was assumed for the straight-line depreciation calculation. This might not necessarily represent the actual situation and should therefore be considered in future research.

\section{Lifetime of the Asset}

Similarly, the lifetime of the asset was assumed to be 15 years. However, the true lifetime of the equipment may vary substantially depending on the respective design of the machines and use over the lifetime of the equipment.

\section{Tax Rate}

The marginal income tax rates for corporations are based on the respective taxable income of a corporation. In accordance with the progressive rate schedule as given in section 11 (b) (1) of the Internal Revenue Code marginal tax rates vary between 15 and 39\%. A marginal tax rate of 35\% was chosen in the depreciation calculation, which represents companies with a taxable income between $\$ 10$ million and $\$ 15$ million. In this case the tax amounts to $\$ 3.4$ million plus $35 \%$ of the taxable income over \$10 million (Jones, 1998).

\section{Discount Rate}

In order to compute the net present value, it is necessary to discount future benefits as well as costs. This discounting reflects the time value of money. Benefits and costs are worth more if they are experienced sooner. The higher the discount rate, the lower is the present value of future cash flows. For typical investments, with costs concentrated in early periods and benefits following in later periods, raising the discount rate tends to reduce the net present value.

The discount rate is also referred to as the opportunity cost of capital because it is the return foregone by investing in a project rather than investing in securities. Consequently the discount rate chosen also reflects the risk-level of a project. A discount rate of $15 \%$ was chosen for the scenarios in order to calculate the net present value of the annual tax shields, as investors use discount rates of $15-20 \%$ as the hurdle rate for investments (Casten, 2001). This is a relatively low discount rate suggesting that the tax shields generated by depreciation are considered to be a relatively certain income. In calculating a net present value, a safe dollar is worth more than a risky one. Therefore it is legitimate to apply a discount rate, which is comparable to investments in US Treasury bonds (Brealey and Myers, 2000).

\section{Normalized Method of Accounting}

According to tax law provisions, public utility property predominantly used to "furnish or sell electricity, water, sewage disposal services, gas or steam" only qualifies for depreciation under MACRS if the normalization method of accounting is used. Normalized accounting requires that the income tax savings from accelerated depreciation, investment credits and interest paid on funds used during construction are amortized over the life of a project ( $\mathrm{CCH}, 1997$, par.140). Normalized accounting is utilized by most investor-owned utilities as a way of protecting the company against unforeseen changes in future income tax rates and state/federal law that govern 
their operation. Another way of dealing with those savings would be flow-through accounting, where the savings would be passed on to a utility's customer in the year that they occur.

In our analysis it is assumed that the investor, if it were a public utility, uses the normalization method of accounting for the respective savings so that accelerated depreciation would be applicable (Sullivan et al. 2000). 


\section{Results and Discussion}

\subsection{Results for 40 MWe Systems}

In this section, we first present the results for a $40 \mathrm{MWe}$ cogeneration system for illustrative purposes alone. We then summarize the results for different sizes of cogeneration systems, following the classification given in Table 1.

In the straight-line depreciation method the book value of the asset is reduced much faster, as expected, when a 7-year schedule is applied (see Figure 1). The annual depreciation for the 7-year schedule for the $40 \mathrm{MW}$ system is approximately \$3.05 Million, whereas the annual depreciation is $\$ 1.4$ Million for a 15-year schedule. Consequently, the present value of the tax shield achieved by the 7 -year schedule is higher ( $\$ 5.8$ Million) than the tax savings achieved by depreciating over 15 years ( $\$ 4.5$ Million).

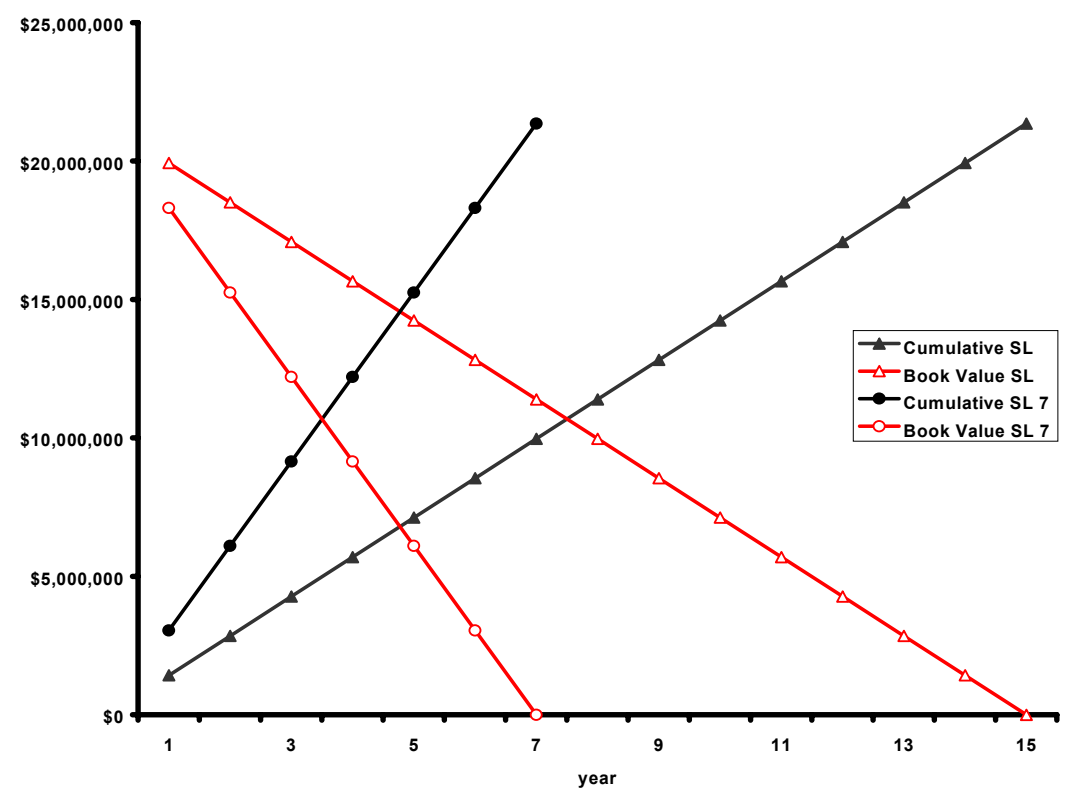

Figure 1. Comparison of cumulative depreciation and book value for the investments in a 40 MWe cogeneration system for a 15 year depreciation period (cumulative SL) and a 7 year depreciation period (cumulative SL 7) using the straight line depreciation method. Also depicted is the book value of the investment for a depreciation period of 15 years (BV-SL) and 7 years (BV-SL7).

A similar result is obtained when comparing results of the declining balance method for a 7-year and a 15-year period. According to the Internal Revenue Code it is legitimate to apply the 150percent declining balance method for the 15-year schedule and the 200-percent declining balance method to the 7-year schedule (see Figure 2). The annual depreciation for the 15-year schedule declines from $\$ 2.1$ Million in year 1 to $\$ 489,000$ in year 15 , whereas the values for the 7-year method range from $\$ 6.1$ Million in year 1 to $\$ 810,000$ in year 7 . The respective tax shields for 
this specific method amount to $\$ 4.1$ Million for the 15-year approach and to \$5.6 Million for the 7 -year period. This method offers advantages during the first years as it offers larger depreciation amounts, which at the same time transform into more substantial tax savings. This effect however seems to be alleviated by the relative small annual depreciation amounts during the last years of the respective schedules. In fact compared to the previous values of the tax shields achieved when using the straight-line method, the application of the declining balance method alone results in lower tax savings than the straight-line method. Therefore the switchover method should be applied.

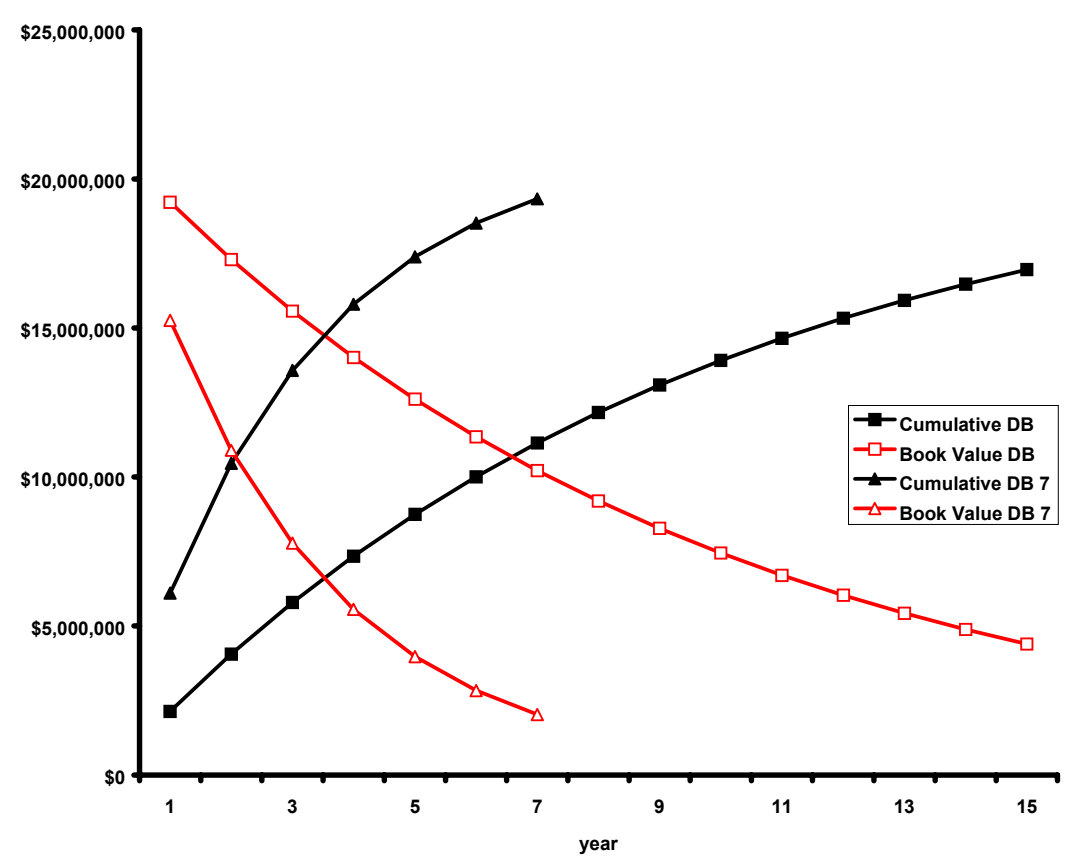

Figure 2. Comparison of cumulative depreciation and book value for the investments in a 40 MWe cogeneration system for a 15 year depreciation period (cumulative DB) and a 7 year depreciation period (cumulative $D B$ 7) using the declining balance depreciation method. Also depicted is the book value of the investment for a depreciation period of 15 years (Book Value$D B$ ) and 7 years (Book Value DB 7).

As discussed above it is possible to switch from a declining balance depreciation to a straight-line depreciation when, after a few years, it is more profitable to depreciate under straight-line condition than to further employ the declining balance method. To apply a combination of the declining balance method and the straight-line method and thus taking advantage of the increased tax savings of the declining balance method at the beginning of the period and the stability of the straight-line method for the following years, it is necessary to determine the switchover year, i.e. the year where the straight-line method generates higher savings than the declining balance method. Figure 3 shows how the switchover years have been determined. 


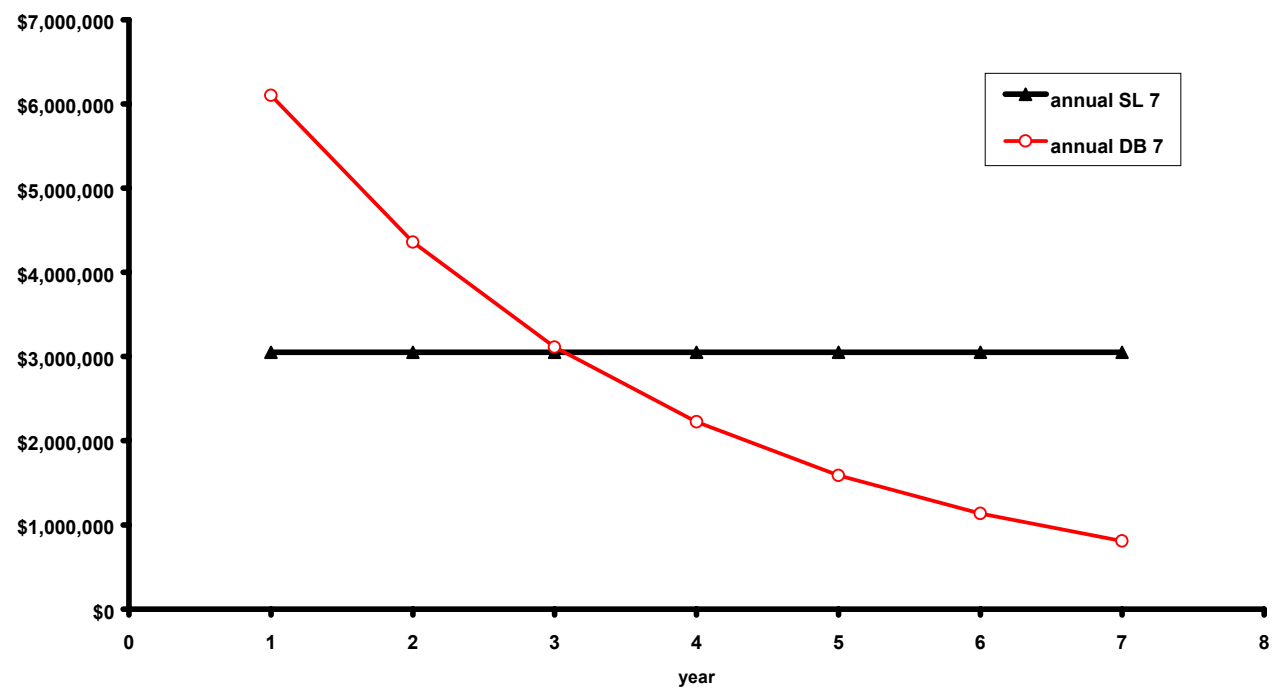

Figure 3. Comparison of the declining balance and straight-line depreciation method for a 7-year schedule for a $40 \mathrm{MWe}$ cogeneration system.

Figure 3 suggests that the switchover is most attractive after year three, because year four offers a larger tax shield using the straight-line depreciation as opposed to the declining balance depreciation. For the 15-year schedule the switchover takes place in year 4.

The declining balance method with switchover to straight-line depreciation results in present values for tax shields of \$5.0 Million for the 15-year schedule and of \$7.2 Million for the 7-year period. Compared to the tax savings created by the other methods for a 7-year depreciation schedule compared to 15 years, the combined method with switchover after 3 years offers increased benefits.

Figure 4 compares the impact of the different depreciation methods and schedules on the costs for the power produced, assuming equipment lifetime of 15 years and an availability of 8000 hours/year. The capital costs are expressed per $\mathrm{kWh}$ of produced electric energy. The calculation is based on the overall capital cost invested and the annual operating and maintenance costs reduced by the respective tax shield effected by the applied depreciation method. It excludes fuel costs and other variable O\&M costs. Figure 4 shows that the 7-year switchover method offers the largest financial benefits for the investor in a cogeneration facility. Under the 7-year switchover depreciation method the production costs of power would be reduced by $0.06 \mathrm{cts} / \mathrm{kWh}$ relative to the 15 year declining balance method, or a reduction by $7 \%$. 


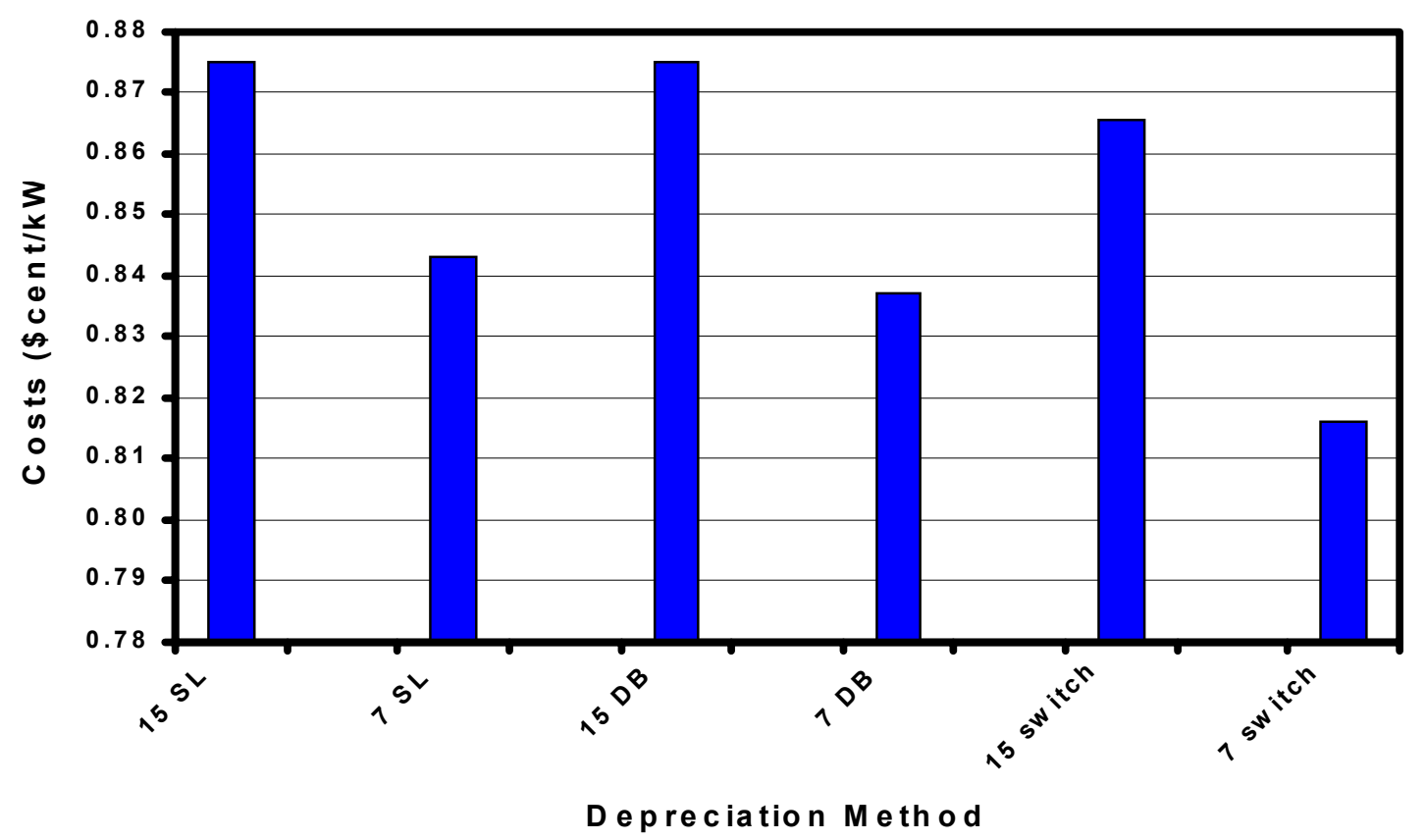

Figure 4. The cost of power generation (only capital and fixed O\&M costs, excluding fuel and variable O\&M costs) under different depreciation methods and schedules, expressed per $\mathrm{kWh}$ of power produced in a $40 \mathrm{MWe}$ cogeneration system.

\subsection{Results for 100 MWe Systems}

In this section, we present the results for a 100 MWe cogeneration system for illustrative, as currently a large proportion of the cogeneration capacity brought online consists of large scale units (> $100 \mathrm{MWe}$ or more).

In the straight-line depreciation method the book value of the asset is reduced much faster, as expected, when a 7-year schedule is applied. The annual depreciation for the 7-year schedule for the 100 MW system is approximately $\$ 7.17$ Million, whereas the annual depreciation is $\$ 3.35$ Million for a 15-year schedule. Consequently, the present value of the tax shield achieved by the 7-year schedule is higher ( $\$ 10.4$ Million) than the tax savings achieved by depreciating over 15 years (\$6.8 Million). 


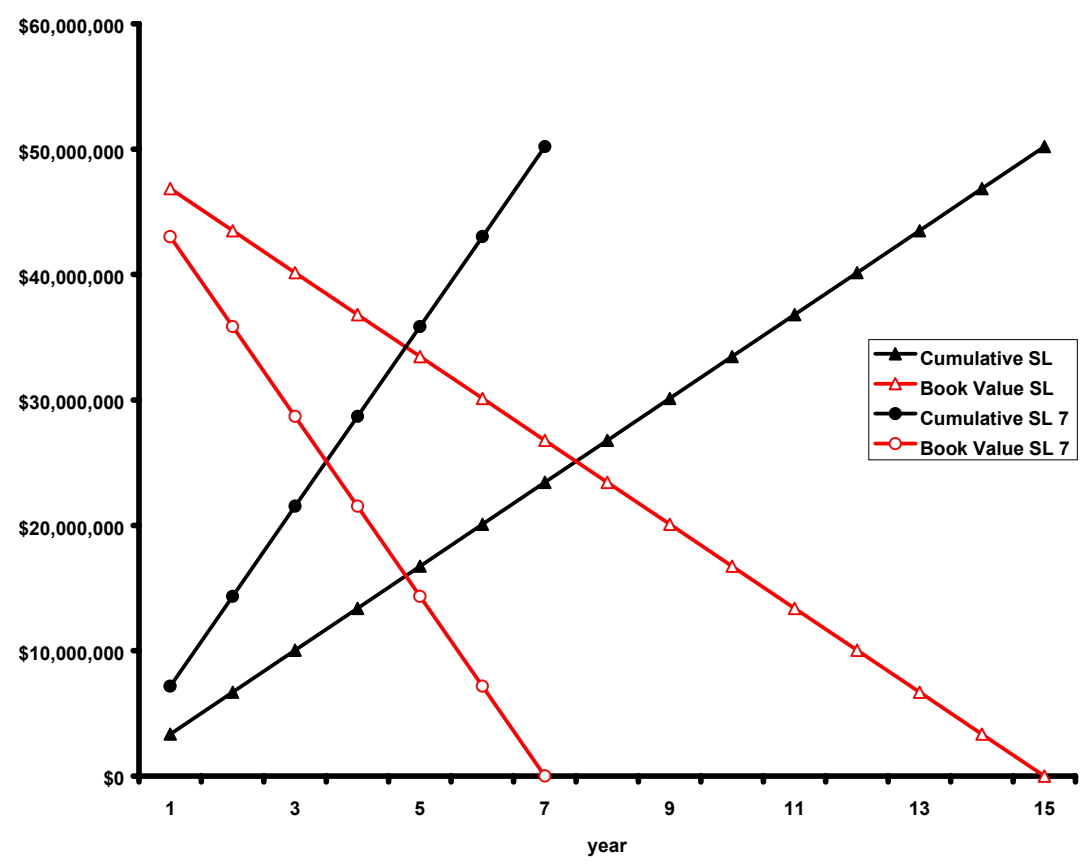

Figure 5. Comparison of cumulative depreciation and book value for the investments in a 100 MWe cogeneration system for a 15 year depreciation period (cumulative SL) and a 7 year depreciation period (cumulative SL 7) using the straight line depreciation method. Also depicted is the book value of the investment for a depreciation period of 15 years (BV-SL) and 7 years (BV-SL7).

A similar result is obtained when comparing results of the declining balance method for a 7-year and a 15-year period. The annual depreciation for the 15-year schedule declines from $\$ 5.0$ Million in year 1 to $\$ 1.1$ Million in year 15, whereas the values for the 7-year method range from $\$ 14.3$ Million in year 1 to $\$ 1.9$ Million in year 7. The respective tax shields for this specific method amount to \$6.9 Million for the 15-year approach and to \$11.1Million for the 7-year period. This method offers advantages during the first years as it offers larger depreciation amounts, which at the same time transform into more substantial tax savings. Similar as the results found for the $40 \mathrm{MW}$ system, it is best to apply the switchover method for depreciation. 


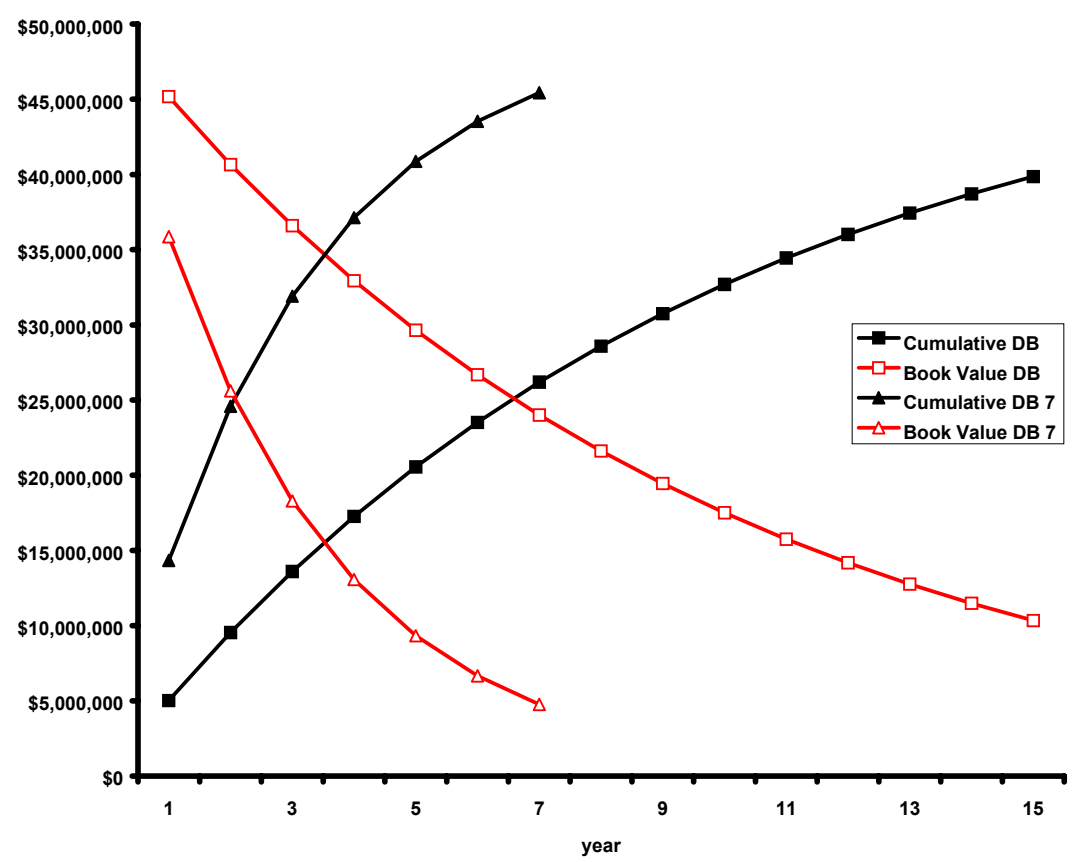

Figure 6. Comparison of cumulative depreciation and book value for the investments in a 100 MWe cogeneration system for a 15 year depreciation period (cumulative DB) and a 7 year depreciation period (cumulative $D B$ 7) using the declining balance depreciation method. Also depicted is the book value of the investment for a depreciation period of 15 years $(B V-D B)$ and 7 years ( $B V-D B 7)$.

As discussed above it is possible to switch from the declining balance depreciation to a straightline depreciation when, after a few years, it is more profitable to depreciate under straight-line condition than to further employ the declining balance method. To apply a combination of the declining balance method and the straight-line method and thus taking advantage of the increased tax savings of the declining balance method at the beginning of the period and the stability of the straight-line method for the following years, it is necessary to determine the switchover year, i.e. the year where the straight-line method generates higher savings than the declining balance method. Figure 7 shows how the switchover years have been determined. 


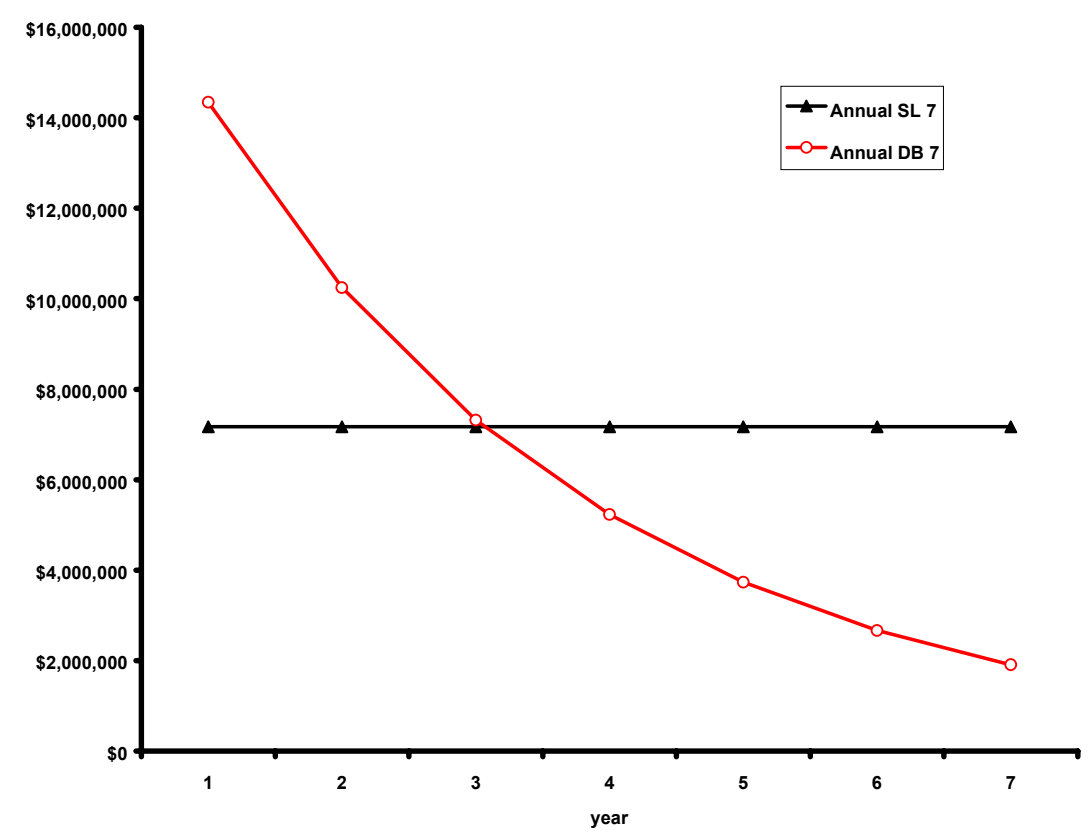

Figure 7. Comparison of the declining balance and straight-line depreciation method for a 7-year schedule for a $100 \mathrm{MWe}$ cogeneration system.

Figure 7 suggests that the switchover is most attractive after year three (as found for systems with a 40 MW capacity), because year four offers a larger tax shield using the straight-line depreciation as opposed to the declining balance depreciation. For the 15-year schedule the switchover takes place in year 4.

The declining balance method with switchover to straight-line depreciation results in present values for tax shields of \$7.9 Million for the 15-year schedule and of \$13.5 Million for the 7-year period. Compared to the tax savings created by the other methods for a 7-year depreciation schedule compared to 15 years, the combined method with switchover after 3 years offers increased benefits.

Figure 8 compares the impact of the different depreciation methods and schedules on the costs for the power produced, assuming equipment lifetime of 15 years and an availability of 8000 hours/year. The capital costs are expressed per $\mathrm{kWh}$ of produced electric energy. The calculation is based on the overall capital cost invested and the annual operating and maintenance costs reduced by the respective tax shield effected by the applied depreciation method. It excludes fuel costs and other variable O\&M costs. Figure 8 shows that the 7 -year switchover method offers the largest financial benefits for the investor in a cogeneration facility. Under the 7-year switchover depreciation method the production costs of power would be reduced $7.1 \%$ relative to the 15 year declining balance method. 


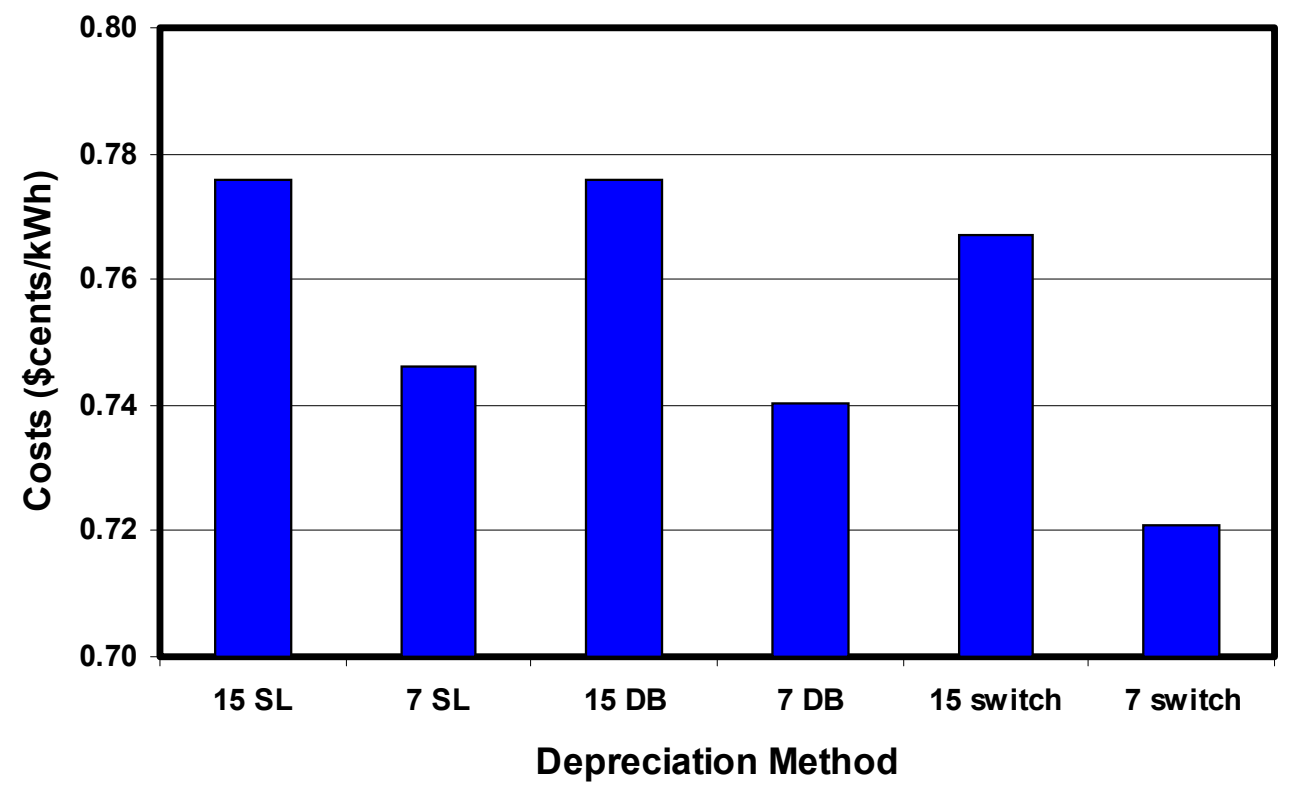

Figure 8. The cost of power generation (only capital and fixed O\&M costs, excluding fuel and variable $O \& M$ costs) under different depreciation methods and schedules, expressed per $k W h$ of power produced in a $100 \mathrm{MWe}$ cogeneration system.

\subsection{Results for the Other Systems}

The same calculations where conducted for the cogeneration systems with different capacities (see Table 1). Generally, similar results were observed for the other system sizes. Although, the costs for producing power vary from system to system, the 7-year switchover method proved to provide the largest tax shields. Also, for all systems the switchover would be most attractive after the third year for the 7-year method and after the fourth year for the 15-year method respectively. Table 2 summarizes the results for the other cogeneration systems. 
Table 2. Net present value of the tax shield and cost per $k$ Wh of power produced for cogeneration systems of different capacities, using the method described above and the equipment characteristics as given in Table 1.

\begin{tabular}{|c|c|c|c|c|c|c|}
\hline System & 1 MW & 5 MW & $10 \mathrm{MW}$ & $25 \mathrm{MW}$ & $40 \mathrm{MW}$ & $100 \mathrm{MW}$ \\
\hline \multicolumn{7}{|c|}{ PV of tax shield (\$) } \\
\hline $15 \mathrm{SL}$ & 160,108 & 460,913 & 889,608 & $1,538,531$ & $2,913,972$ & $6,849,136$ \\
\hline $7 S L$ & 244,109 & 702,730 & $1,356,340$ & $2,345,720$ & $4,442,784$ & $10,442,526$ \\
\hline $15 \mathrm{DB}$ & 160,131 & 460,977 & 889,732 & $1,538,745$ & $2,914,377$ & $6,850,088$ \\
\hline $7 \mathrm{DB}$ & 259,719 & 747,668 & $1,443,071$ & $2,495,721$ & $4,726,885$ & $11,110,291$ \\
\hline 15 switch & 184,594 & 531,402 & $1,025,659$ & $1,773,824$ & $3,359,616$ & $7,896,597$ \\
\hline 7switch & 314,931 & 906,611 & $1,749,850$ & $3,026,274$ & $5,731,751$ & $13,472,173$ \\
\hline \multicolumn{7}{|c|}{ Cost per kWh (\$/kWh) } \\
\hline $15 \mathrm{SL}$ & 0.0206 & 0.0118 & 0.0109 & 0.0085 & 0.0088 & 0.0078 \\
\hline $7 \mathrm{SL}$ & 0.0199 & 0.0114 & 0.0105 & 0.0082 & 0.0084 & 0.0075 \\
\hline $15 \mathrm{DB}$ & 0.0206 & 0.0118 & 0.0109 & 0.0085 & 0.0088 & 0.0078 \\
\hline $7 \mathrm{DB}$ & 0.0198 & 0.0113 & 0.0104 & 0.0081 & 0.0084 & 0.0074 \\
\hline 15 switch & 0.0204 & 0.0117 & 0.0108 & 0.0084 & 0.0087 & 0.0077 \\
\hline 7switch & 0.0193 & 0.0111 & 0.0102 & 0.0080 & 0.0082 & 0.0072 \\
\hline
\end{tabular}

Notes: SL: straight line depreciation; DB: declining balance depreciation; switch: declining balance with switchover to straight line depreciation; 7: 7 years depreciation period; 15: 15 year depreciation period.

\subsection{The Cost of different Depreciation Systems to the U.S. Treasury}

Although a shortened depreciation cycle would offer substantial benefits to investors in the benefits, at the same time costs may be created because of reduced tax revenues for the U.S. Treasury. However, the costs due to reduced tax income from the accelerated depreciation of cogeneration equipment may be offset by increased income due to the productive use of the money freed up by accelerated depreciation, as well as reduced power costs to investors. While we can not estimate the likely impact of productive use of saved capital costs, the likely balance is zero or positive for the treasury.

Below we estimate the reduced income due to the accelerated depreciation of cogeneration equipment, and to estimate the capital freed up for investments by cogeneration investors and industries. This excludes the increased tax income due the investments by these parties. The exact cost caused by such a measure depends on various factors and also varies with the chosen depreciation method, it is possible to make a rough estimate. We assume that an estimated 20 GWe of cogeneration systems will be constructed which qualify for the changed tax depreciation methods as discussed above. If it is assumed that these $20 \mathrm{GW}$ will be achieved by installing predominantly $40 \mathrm{MW}$ systems, which would accrue an estimated tax shield of \$7.2 Million using the 7-depreciation schedule with switchover, compared to 4.1 Million for the 15 year declining balance that is currently used for CHP systems not selling power to third parties. The change in depreciation method would reduce the tax revenues by $\$ 3.1$ Million. Assuming $40 \mathrm{MWe}$ systems, 500 units are constructed to achieve an additional total installed capacity of $20 \mathrm{GW}$, this would result in total reduced revenues for the U.S. Treasury of \$1.55 Billion (\$1551 Million, net present value) from the accelerated depreciation of cogeneration investments. 
Table 3 summarizes the size of the reduced revenue for the U.S. Treasury for installing $20 \mathrm{GW}$ of cogeneration, using either one of the CHP systems as defined in Table 1. The values in Table 1 provide an estimate of the size of the lost revenue (excluding income of productive use of freed up capital). In reality, when applying a different depreciation method for cogeneration systems, the net revenue change will be somewhere in the middle of the estimates given in Table 3. Also, note that this calculation assumes that $20 \mathrm{GW}$ of cogeneration would be built anyway. If the alternative would be $20 \mathrm{GW}$ of central power generation stations the tax revenues are likely to be different.

Table 3. Net present value of lost revenue due to accelerated depreciation of cogeneration equipment for the U.S. Treasury, excluding increased tax income due to productive use of the freed up capital. We use a 7-year schedule with switchover to straight-line, compared to the current 15 year declining balance method, assuming construction of $20 \mathrm{GW}$ of capacity using different sizes of systems.

\begin{tabular}{|c|c|c|}
\hline CHP System & $\begin{array}{c}\text { Number of } \\
\text { systems required } \\
\text { to reach 20 GW }\end{array}$ & $\begin{array}{c}\text { Cost to } \\
\text { Treasury } \\
\text { (Million \$) }\end{array}$ \\
\hline $1 \mathrm{MW}$ & 20,000 & 3,097 \\
\hline $5 \mathrm{MW}$ & 4,000 & 1,783 \\
\hline $10 \mathrm{MW}$ & 2,000 & 1,721 \\
\hline $25 \mathrm{MW}$ & 800 & 1,190 \\
\hline $40 \mathrm{MW}$ & 500 & 1,409 \\
\hline $100 \mathrm{MW}$ & 200 & 1,379 \\
\hline
\end{tabular}

As stated before, the net effect on tax income for the US Treasury may be zero or positive depending on the use of the freed up capital due to the accelerated depreciation. The results in Table 3 do not account for the increased tax income.

\subsection{Uncertainties and Recommendations for Future Research}

The preceding calculations are subject to several uncertainties mostly due to the assumptions necessary to estimate the impact on a general level. The magnitude of the tax shield will definitely change with choosing a different tax rate and discount rate. Also, as we use general data we were not able to estimate the total impact on power production costs. This can be done assuming a specific region in the U.S. and natural gas price. For this study we have not done this to not further complicate the analysis as well as to present a general estimate of the likely impact of changes in the tax code for cogeneration systems. Finally, the impact on the financial viability (and hence likelihood) of a cogeneration project will depend on the changes in net income due to the tax code changes. As we were unable to estimate the changes in net income from sales of power and/or heat, we only estimated the impact on capital and fixed operation and maintenance costs. Also, the size of the lost revenue for the U.S. Treasury will depend on the total change in income of the investing company (see also below with respect to the Allowable Minimum Tax). Many variables affect the income changes. It is only possible to evaluate the full impact on the viability for the investor and impact on tax revenues using case-studies. 
In order to create an even more complete picture of the mechanics and effects of various tax incentives on investments in the field of combined heat and power generation, it is necessary to take into account and further examine the following aspects:

Change in the depreciation schedule versus tax credit. Tax credits are increasingly considered to provide an effective incentive for investments in combined heat and power. Actually, tax credits are preferred over shortened depreciation cycles by some experts as it allows to receive the benefits of the investment in the tax year the facility is placed in service. However, the U.S. Treasury does generally not approve of tax credits, as it is seen as a distortion of the tax system. Future research should concentrate on the direct comparison between tax credits and shortened depreciation cycles, and impact on financial attractiveness of investments in cogeneration.

Alternative Minimum Tax.. The alternative minimum tax (AMT) system is a federal tax system parallel to the regular income tax system designed to prevent large companies from escaping taxation altogether by utilizing numerous tax credits and benefits available to them. In the context of depreciation this means that although a companies might receive tax saving through depreciation by investing in combined heat and power technologies, this might not result in an actual benefit, if a firm is subject to AMT, as this would increase the positive adjustment to regular taxable income required under AMT. As depreciation benefits are not transferable into following years the investment benefits would be lost for this company and thus non-existent. This highlights the need to assess the share of companies under AMT of the companies likely to invest in cogeneration installations.

Effect on tax income of the US Treasury. As stated above it is difficult to estimate the net effect of the effect of accelerated depreciation, due to the uncertainties in the use of the capital costs saved by the measure. For example, the reduced project costs due to the accelerated depreciation will lead to lower energy costs to the users of the power (and heat). The reduced energy costs may be invested in productivity improvement and other (taxable) investments. The total effect of the accelerated depreciation may hence be positive for the US economy and the Treasury, depending on the form the freed up capital is used within the economy. We have been unable to estimate this effect, but an economic analysis of capital spending, industrial productivity and tax income may provide more insights in the total effect on tax income. 


\section{Conclusion}

We investigated and compared several depreciation methods to assess the effectiveness of possible policy measures with respect to the depreciation schedules for investments in combined heat and power plants in the United States. We assessed the different depreciation methods for cogeneration projects of various sizes (ranging from $1 \mathrm{MW}$ to $100 \mathrm{MW}$ ). We evaluated the impact of different depreciation schedules on the tax shield, and the resulting tax savings to potential investors. We showed that a shorter depreciation cycle could have a substantial impact on the cost of producing power, making cogeneration more attractive. The savings amount to approximately $6-7 \%$ of capital and fixed operation and maintenance costs, when changing from the current system to a 7 year depreciation scheme with switchover from declining balance to straight line depreciation. It is not sure if all companies would benefit similarly from a changed tax treatment due to the specific situation of a company with regards to tax treatment.

\section{Acknowledgments}

This work was supported by the Office of Atmospheric Programs of the U.S. Environmental Protection Agency, prepared for the U.S. Department of Energy under Contract No. DE-AC0376SF00098. We wish to thank Bruce Hedman (Onsite Energy) and Neal Elliott (ACEEE) for providing data and inputs in the analysis. We also thank Thomas Casten (Private Power LLC) and Tom Kerr (US EPA ) for their insightful comments on an earlier version of this paper. Any errors within this paper remain the responsibility of the authors. The views expressed in this paper do not necessarily reflect those of the U.S. Environmental Protection Agency, the U.S. Department of Energy, or the U.S. Government. 


\section{References}

Brealey R.A. and Myers S.C., 2000. Principles of corporate finance, Irwin McGraw Hill, Boston

Casten T.R. and Hall M.C., 1998. Barriers to deploying more efficient electrical generation and combined heat and power, Trigen Energy Corporation

Casten, T.R., 2001. Personal Communication from Thomas R. Casten, Private Power LLC, Oak Brook, IL, October $31^{\text {st }}, 2001$.

Commerce Clearing House (CCH), 1997. Depreciation guide, featuring MACRS, Commerce Clearing House, Chicago, IL

Hall M., 2001. Full Hearing Testimony on the Senate Bill 933 before the Senate Committee on Energy and Natural Resources, energy.senate.gov/hearings

Hedman B., 2001. Personal communication with Bruce Hedman, ONSITE Energy Corporation, July 2001

Jones S.M., 1998. Principles of Taxation for Business and Investment Planning, Irwin McGrawHill, Boston

Major W., and Davidson K., 1998. Gas turbine power generation combined heat and power, Environmental analysis and policy considerations, Gas Research Institute

Orlando J.A., 1996. Cogeneration design guide, American Society of Heating, Refrigerating and Air-Conditioning Engineers, Inc., Atlanta, GA.

Pratt J., 1999. Financial accounting in an economic context, South-Western College Publishing:

Sullivan W.G., Bontadelli, J.A., and Wicks E.M., 2000. Engineering Economics, Prentice Hall, Upper Saddle River, NY

Thuesen G.J. and Fabrycky W.J., 2001. Engineering Economy, Prentice Hall, Upper Saddle River, NY

Vasche J.D., 1985. Cogeneration equipment investments: The effects of rapid amortization, Reports of the Legislative Analyst, Sacramento, CA 